\title{
Empirical Analysis on Impact of FDI on the Level of Urbanization in Costal Areas
}

\author{
Cao Can-Ming ${ }^{1,2}$, Duan Jin-Jun ${ }^{2}$ \\ ${ }^{1}$ Applied and Technological School, ${ }^{2}$ Dongwu Business School Soochow University (China) \\ grass11@sina.com, dijdqr@.sina.com
}

Received: November 2014

Accepted: January 2015

\section{Abstract:}

Purpose: There is a close relationship between FDI and the level of urbanization. the objective of this research is to analyze the relationship between FDI and the level of urbanization in Jiangsu and Guangdong provinces in costal areas.

Design/methodology/approach: The author uses the modern econometric methods by panel unit root test, cointegration test, random effects models and fixed effects models, and the data of FDI (2000-2012), urbanization rate, industrial structure and regional GDP of Nanjing, Xuzhou, Suzhou, Wuxi and other 13 cities in Jiangsu Province, Guangzhou, Shenzhen and other 19 cities in Guangdong province, researches the relationship between FDI and urbanization rate.

Findings: Models show, FDI was closely correlated with urbanization rate in Jiangsu province and Guangdong province, the highly correlated with industrial structure, while it negatively correlated with the growth of GDP, and the degree of correlation is not high in Jiangsu province, but the high negative correlation in Guangdong province. The results shows the industrial structure and the urbanization rate mainly cause FDI growth.

Research limitations/implications: There are many provinces in costal areas of China, this paper just research the relationship between FDI and the level of urbanization in Jiangsu province and Guangdong province, there are some limitations in the study areas and results. 
Originality/value: The study was the first to successfully apply on random effects model and fixed effects model to study the relationship between FDI and the level of urbanization in coastal areas by competitive analysis. Guangdong and Jiangsu province are the most developed regions, they are the most representative provinces in costal areas of China. Taking these two province as an example, we can analyze the relationship between FDI and the level of urbanization in central and western regions.

Keywords: urbanization, FDI, urbanization rate, industrial structure, costal areas

\section{Introduction}

Urbanization has become the key of Chinese economic development and transition, either academia or the Central Committee of Communist Party attaches great importance to urbanization. The Central Committee held a working meeting of urbanization in Beijing on December 12th, 2013, the meeting stressed: promoting urbanization must proceed from the primary stage of socialism in China's basic national conditions, follow the law, and urbanization will go to ripe. We must promote urbanization not only actively but also safely and solidly with the solid direction and the implemented measures. We should focus on improving the quality of urban development, population urbanization level increased steadily. Be people-oriented, we should promote human-centered urbanization, improving the quality of the urban population and the quality of residents' life, it is the primary task to promote stable employment and achieve urbanization orderly of the resident population.

Urbanization process affected by many factors, foreign direct investment (FDI) is one of the main driving forces of urbanization. FDI is that the investor uses the capital in the production and management and has a certain control over the operations, according to International Monetary Fund (IMF) definition. FDI is not only great to meet the shortage of funds in developing countries requirements, but also provides advanced technology and management experience to the host.

Foreign direct investment has significant effect on economic growth and employment, and foreign direct investment enterprises can promote the product structure, upgrade industrial structure and technical structure. An important symbol of upgrading industrial structure is nonagricultural of employed population, characterized by primary industry employment proportion to drop, the second and third industry employment proportion increased.

Jiangsu province and Guangdong province are outstanding provinces in the Yangtze River Delta and the Pearl River Delta, which are Chinese fastest growing economy in the regions, the urbanization level are higher, and have entered the urbanization quality rapid promotion stage. 
FDI has become the important force to promote the development of economy and the city. About 35.76 billion USD FDI was received in Jiangsu province in 2012, an increase of $11.3 \%$, accounting for a quarter of the country's total FDI, the scale of FDI keeps the size of the country's first in the last ten years. The presence of FDI not only brings the improvement of the tax, employment, exports, but also prompts enterprises of Jiangsu province from low-end to high-end in the fierce international competition. The structure of utilizing FDI further optimized in Jiangsu province, the actual use of FDI increased by $45.4 \%$ in three equipment manufacturing industries of general equipment, transportation equipment and special equipment, the actual use of FDI in service industry increased by $31.3 \%$. The actual arrival of FDI in the primary industry, secondary and tertiary industry optimized for $4.2 \%: 64.6 \%: 64.6 \%$. 6043 projects of FDI were newly approved in Guangdong province in 2012, fell by $14.1 \%$ year on year; Contracted foreign investment reached 34.994 billion USD, increased by $0.9 \%$, The actual use of foreign capital was 23.549 billion USD, an increase of $8.0 \%$, accounting for $21.1 \%$ of the total amount of the actual use of FDI, an increase of $2.5 \%$ over the previous year (Figure 1).

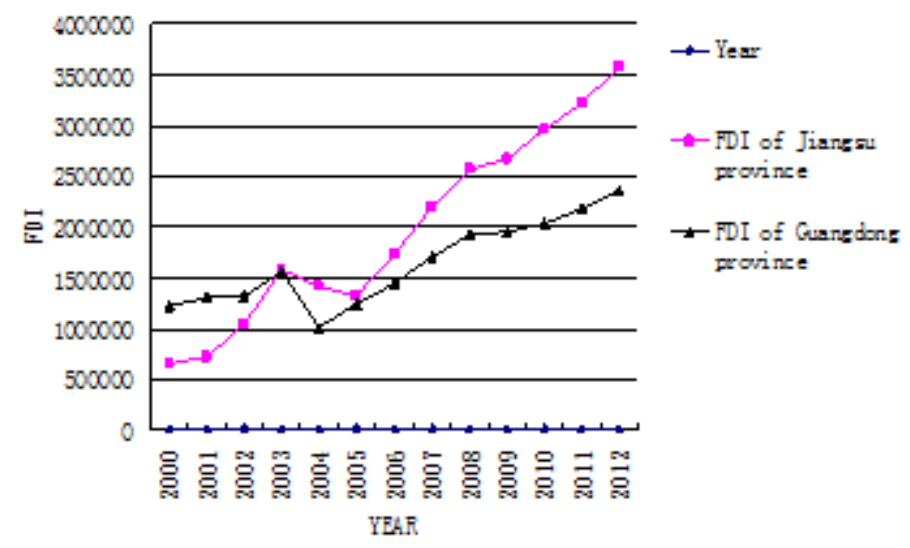

Figure 1. FDI of Jiangsu and Guangdong province in China (2000-2012)

\section{Literature Review}

\subsection{Urbanization Depends on FDI in Developing Countries}

Some scholars thought that urban system in developing countries as well as the speed of urbanization and spatial structure depends on its role in the process of capital accumulation in industrialized countries (Friedmann, 1986; Kentor, 1981; Portes \& Johns, 1986; Timbedake \& Kentor, 1983); developing countries can't get rid of dependent urbanization in the new global order. They asserted that investment dependence has lag effect after transnational quantitative analysis, and draw the conclusion: the external economic dependence for undeveloped countries has not long-term effects in urbanization model and urban growth, and FDI has a negative effect on the undeveloped countries. Study by Chase-Dunn (1975) supported the 
theoretical arguments, the qualitative research results found that foreign investment penetration (i.e., the ratio of foreign investment to the total capital stock) has a negative effect on per capita GNP growth in 1965-1975. Research by Timberlake and Kentor (1983) showed that the higher the dependence on foreign capitals, relative to the economic development level, the greater the population in the city by panel regression method, the result supports the hypothesis that the more the stock of foreign investment in Third World countries, the higher the level of over-urbanization. Kentor (1981) thought it's more appropriate that the peripheral countries urbanization understood as attachment theory. Because when foreign investment increased urbanization rate, it was selectively improved the informal sector and the tertiary industry of the city's economic sector. Further, accompanying with the positive effects of these selective investment dependence, it limited the periphery industry growth in the labor department, and led to excessive urbanization.

\subsection{FDI Has Positive Effect on Developing Countries}

Some scholars believed that developing countries can actively participate in the world economy and ensure the positive output of the city (Kasarda \& Crenshaw, 1991; George, 2007; Fujita \& $\mathrm{Hu}, 2001)$. International capital flows and international production were regarded as beneficial factors in the process of urbanization. Firman, Kombaitan and Pradono (2007) analyzed Indonesia's urbanization, and found that until the late 1990s, FDI is mainly concentrated in metropolitan area in Jakarta, the urbanization and economic development are driven by the domestic investment in the most areas of Indonesia, this situation has not changed in 2000. Study by Clark (1998) also suggested that the urbanization of Africa and Asia is the regional response to the new global economic order in recent years, the capital from advanced economies created the manufacturing and service sector jobs, and led to the growth of the cities and urbanization advancement with the agricultural labor force. As a multinational capitalism's impact on developing world, such as Africa, Asia and Latin America, urbanization is indirect result.

\subsection{FDI and Economic Growth, Industrial Structure}

Romer (1990, 1994) emphasized technology diffusion plays a decisive role on economic sustainable growth in his endogenous growth model in developing countries, especially in small countries and sustained economic growth. As a main channel of technology diffusion, FDI plays an important role in developing countries. Glenn Firebaugh (1992) found both domestic and foreign direct investment contribute to economic development after comparing their effect to the economy. Basing on 40 years' FDI data from industrialized countries to 69 developing countries, Borensztein, De Gregorio \& Lee (1998) tested the effect of FDI on economic growth; 
found that FDI on technology introduction is an important driving factor, and the contribution to economic growth than domestic investment. Blomstrom (1986) tested the effect of FDI on Mexican manufacturing industries; found that it had a significant positive effect on structure efficiency that FDI entered in certain industry. And is closely related to the "modern" part of the industry structure change. Lloyd (1996) studied FDI in Asian areas, thought most FDI focus on the Asia's export-led industries, promoted the transformation of regional industrial structure, and led to re-layout of production activities, formed the so-called "enclave model". Structure adjustment of the host country is the key factor to achieve long-term growth.

Some Chinese scholars thought foreign capital is a new power of urbanization. Ning Yue-Min (1998) and Guang-Zhong, YiXing and Lin (1994) argued that dynamic mechanism of urbanization had been changing from sole-element, two-element to multi-element since the 1999s, Feng-Xuan and Chun (1995, 1997), Yi-Shao and Meng-Jing (2003) clearly put forward that foreign investment is the new power of urbanization of the Pearl River Delta and the Yangtze River Delta. Deng (2000) thought China has formed the dynamic mechanism of exogenous and endogenous urbanization. Chao-Lin (2003) pointed out study mainly focused on the informationization and globalization's impact on global urbanization. Research suggests that the rapid development of world urbanization was related to the two major global processes, the first process is economic globalization, and the second is the rapid growth of service industry. Hong (2001), Yi-Shao and Meng-jing (2003) also studied that the foreign capital played a role in the evolution of the spatial pattern of urbanization.

Xi (2008) thought the level of urbanization is driven by FDI when FDI is stable and reached a large scale. The accumulation of city itself would lead to the rapid development of its own after reaching a certain degree. According to the related data of China's 21 cities from 2003 to 2007, Juan, Feng and Peng-Fei (2011) built up a comprehensive index to measure the level of urbanization, employ panel data to examine whether the FDI has effect on the level of comprehensive urbanization. The results demonstrated that FDI has positive effect on the level of urbanization in the city with high-level of urbanization, while FDI has negative effect when the level of urbanization is low. According to 1984-2010 time-series data of Jiangxi province, Ji-Zeng (2013) used co-integration test and Granger causality test, build a simultaneous equation model, analysis the relationship between three indicators (FDI, urbanization rate, industrial structure) and their influencing factors. They got the following conclusions: first, industrialization is a major means of urbanization; second, the size of the market and the market openness is the main cause of attracting FDI, urbanization has reverse effect on FDI; third, the driving force of economic growth is the urbanization and regional investment.

Some scholars focused on the study of FDI introduction to Chinese overflow. Liu and Parker (2001) found that Foreign Presence (FP), R\&D level and firm size is the most important factor which improves the level of Chinese industrial total factor productivity (TFP). Fang and De-Wen (2004) thought foreign direct investment can promote economic growth and bring changes in 
industrial structure. Foreign direct investment enterprises can promote the product structure, industrial structure upgrading and technological restructuring. Ji-Yong and Yang-Yi (2008) found that it was not obvious of knowledge spillovers of FDI; their technology investment was the most important factor of promoting regional technical progress. Dian-Chun and Yu (2008) considered defective system imprisons the development of FDI technology spillover mechanism. Fei and Jian-Hua (2009) conducted by industry system GMM and found that technology spillover effect of FDI were not significant either short-term or long-term effects. Chang-Biao (2010) thought foreign capital produced spillover not only in the region but also among region, it stimulated and enhanced the productivity performance of the region, also indirectly led to the improvement of other areas of productivity from the regional level.

About FDI and urbanization research literature in this area, Chinese scholars, Rong-Lin (2010) use social statistical software SPSS and data of 13 cities in Jiangsu Province, analyze the correlation of FDI and urban development, it shows it is obvious between FDI and the level of urbanization in different regions, FDI stock on promoting the role of urban development is greater than the incremental role in promoting FDI on urban development. Xiu-Yu and HongQuan (2009) used the panel unit root test, cointegration and error correction models in FDI relations with urbanization of Guangdong Province, the result shows reciprocal causation relationship between FDI and urbanization in long-term, but FDI is not the factor of urbanization in short term. Fan (2011) analyzed cross-sectional data of urbanization rate and FDI, per capita GDP, the proportion of tertiary industry and other variables of Jiangsu, Zhejiang and Shanghai, the result shows it is significant that foreign direct investment contribute to urbanization in Jiangsu, Zhejiang and Shanghai, but its significant level is less than the proportion of tertiary industry and the impact of the per capita GDP to urbanization. Research by Kai-Ming and Cun-Zhang (2010) showed that it has long-term equilibrium relationship between FDI and urbanization, FDI is the Granger cause to improve the level of urbanization. Lin Ji and Lai-Ke (2013) analyze the relationship among Chinese FDI (1978-2011), the urbanization rate and economic growth by VAR model. Studies have shown that the presence of long-term equilibrium relationship between FDI, urbanization and economic growth, FDI is Granger cause of economic growth, and can effectively promote economic growth, but economic growth is not the cause of FDI, the study also found that economic growth improve the level of urbanization, but the level of urbanization is not Granger cause of economic growth, urbanization has a negative effect on economic growth in the short term, but has a positive effect on economic growth in the long term. Based on the timing data of Jiangxi Province from 1984 to 2010, Ji-Zeng (2013) thought industrialization is the primary means of advancing urbanization; market size and market openness is the main reason for attracting FDI, promoting urbanization on FDI inflows have reverse effect; the original power of economic growth is urbanization and regional investment.

These studies focused on FDI on urbanization and urban growth, and less study on relationship between FDI and economic growth, urbanization and industrial structure, and urban industrial 
structure also has influence on FDI. Taking the case of 13 cities in Jiangsu Province and 21 cities in Guangdong province, the author analyzes the relationship between FDI and the level of urbanization, industrialization and economic aggregate by short panel data in this paper. Actually FDI in these cities plays an important role in promoting economic growth, upgrading level of urbanization and improving industrial structure. Figure 2 reflects the FDI trends change from 2000 to 2012 of 34 cities in Jiangsu and Guangdong province.

\section{Model, Data and Methodology}

\subsection{Index Selection and Data Acquisition}

In this thesis, panel data is analyzed from the 13 cities in Jiangsu province and 21 cities in Guangdong province from 2000 to 2012, which include Nanjing, Suzhou, Wuxi, Xuzhou, Changzhou, Nantong, Lianyungang, Huaiyin, Yancheng, Yangzhou, Zhenjiang, Taizhou and Suqian in Jiangsu province, and Guangzhou, Shenzhen, Shaoguan, Zhuhai, Shantou, Foshan, Jiangmen, Zhanjiang, Maoming, Zhaoqing, Yangjiang, Meizhou, Shanwei, Heyuan, Huizhou, Qingyuan, Dongguan, Zhongshan, Chaozhou, Jieyang and Yunfu in Guangdong province. The data comes from "China City Statistical Yearbook (2001-2013)", "Jiangsu Statistical Yearbook (2001-2013)" and "Guangdong Statistical Yearbook (2001-2013).FDI, GDP, UR (urbanization rate), IS (industrial structure) in 2012 of Jiangsu province and Guangdong province are in Table 1.

\begin{tabular}{|c|c|c|c|c|c|c|c|c|c|}
\hline City & $\begin{array}{c}\text { FDI (billion } \\
\text { USD) }\end{array}$ & $\begin{array}{c}\text { GDP (billion } \\
\text { RMB) }\end{array}$ & $\begin{array}{l}\text { UR } \\
(\%)\end{array}$ & $\begin{array}{c}\text { IS } \\
(\%)\end{array}$ & City & $\begin{array}{c}\text { FDI (billion } \\
\text { USD) }\end{array}$ & $\begin{array}{c}\text { GDP (billion } \\
\text { RMB) }\end{array}$ & $\begin{array}{l}\text { UR } \\
(\%)\end{array}$ & $\begin{array}{c}\text { IS } \\
(\%)\end{array}$ \\
\hline Guangzhou & 4.57489 & 1355.121 & 85.02 & 99.5 & Nanjing & 4.13 & 720.157 & 80.2 & 97.4 \\
\hline Shenzhen & 5.2294 & 1295.006 & 100.0 & 99.9 & Wuxi & 4.01 & 756.815 & 72.9 & 98.2 \\
\hline Zhuhai & 1.44677 & 150.3764 & 87.82 & 98.7 & Xuzhou & 1.7 & 401.658 & 56.7 & 90.5 \\
\hline Shantou & 0.13051 & 142.5014 & 69.50 & 94.5 & Changzhou & 3.36 & 396.987 & 66.2 & 96.8 \\
\hline Foshan & 2.34983 & 661.3022 & 94.87 & 98.2 & Suzhou & 9.165 & 1201.165 & 72.3 & 98.5 \\
\hline Shaoguan & 0.17169 & 90.6476 & 53.30 & 85.9 & Nantong & 2.21 & 455.867 & 58.7 & 93 \\
\hline Heyuan & 0.1971 & 61.52596 & 40.46 & 87.3 & Lianyungang & 0.734 & 160.342 & 54.4 & 85.5 \\
\hline Meizhou & 0.11877 & 74.47531 & 43.57 & 78.7 & Huaiyin & 1.202 & 192.091 & 53.5 & 87.1 \\
\hline Huizhou & 1.72787 & 236.755 & 63.90 & 94.6 & Yancheng & 2.111 & 312 & 55.8 & 85.4 \\
\hline Shanwei & 0.34517 & 61.04079 & 54.60 & 83.5 & Yangzhou & 2.138 & 293.32 & 58.8 & 93 \\
\hline Dongguan & 3.36938 & 501.0173 & 88.67 & 99.6 & Zhenjiang & 2.21 & 263.042 & 64.2 & 95.6 \\
\hline Zhongshan & 0.80394 & 244.1043 & 87.92 & 97.5 & Taizhou & 1.45 & 270.167 & 57.9 & 92.9 \\
\hline Jiangmen & 0.86982 & 188.0394 & 63.20 & 92.2 & Suqian & 0.452 & 152.203 & 51.0 & 84.9 \\
\hline Yangjiang & 0.15303 & 88.7033 & 48.00 & 80.2 & & & & & \\
\hline Zhanjiang & 0.08726 & 186.0221 & 38.30 & 79.7 & & & & & \\
\hline Maoming & 0.08004 & 193.6178 & 37.43 & 82.1 & & & & & \\
\hline Zhaoqing & 1.15159 & 146.235 & 42.62 & 83.3 & & & & & \\
\hline Qingyuan & 0.30296 & 102.5032 & 47.93 & 86.1 & & & & & \\
\hline Chaozhou & 0.14208 & 70.66543 & 63.15 & 92.9 & & & & & \\
\hline Jieyang & 0.19166 & 139.6795 & 49.00 & 89.8 & & & & & \\
\hline Yunfu & 0.10535 & 53.02924 & 39.10 & 76.1 & & & & & \\
\hline
\end{tabular}

Table 1. FDI, GDP, UR and IS in 2012 of Jiangsu and Guangdong province in China 


\subsection{Empirical Model and Data}

Empirical models are similar in the literature about FDI and urbanization. It differs mainly in FDI and urbanization indicators and control variables; the paper establishes the following empirical model:

$$
\operatorname{LnFDI} i \mathrm{it}=A_{0}+A_{1} L_{n U R} \text { it }+A_{2} L_{n I S} \text { it }+A_{3} L_{n G D P} \text { it }+E_{i t}
$$

In equation, FDI represents foreign direct investment, UR represents urbanization rate, IS and GDP are control variables, IS represents the industrial structure, GDP represents the economy growth. $\mathrm{i}$ and $\mathrm{t}$ respectively is regions and time, $\mathrm{E}$ is a random disturbance. To eliminate possible heteroscedasticity, all indicators were handled with natural logarithm, denoted LnFDI, LnUR, LnIS, and LnGDP.

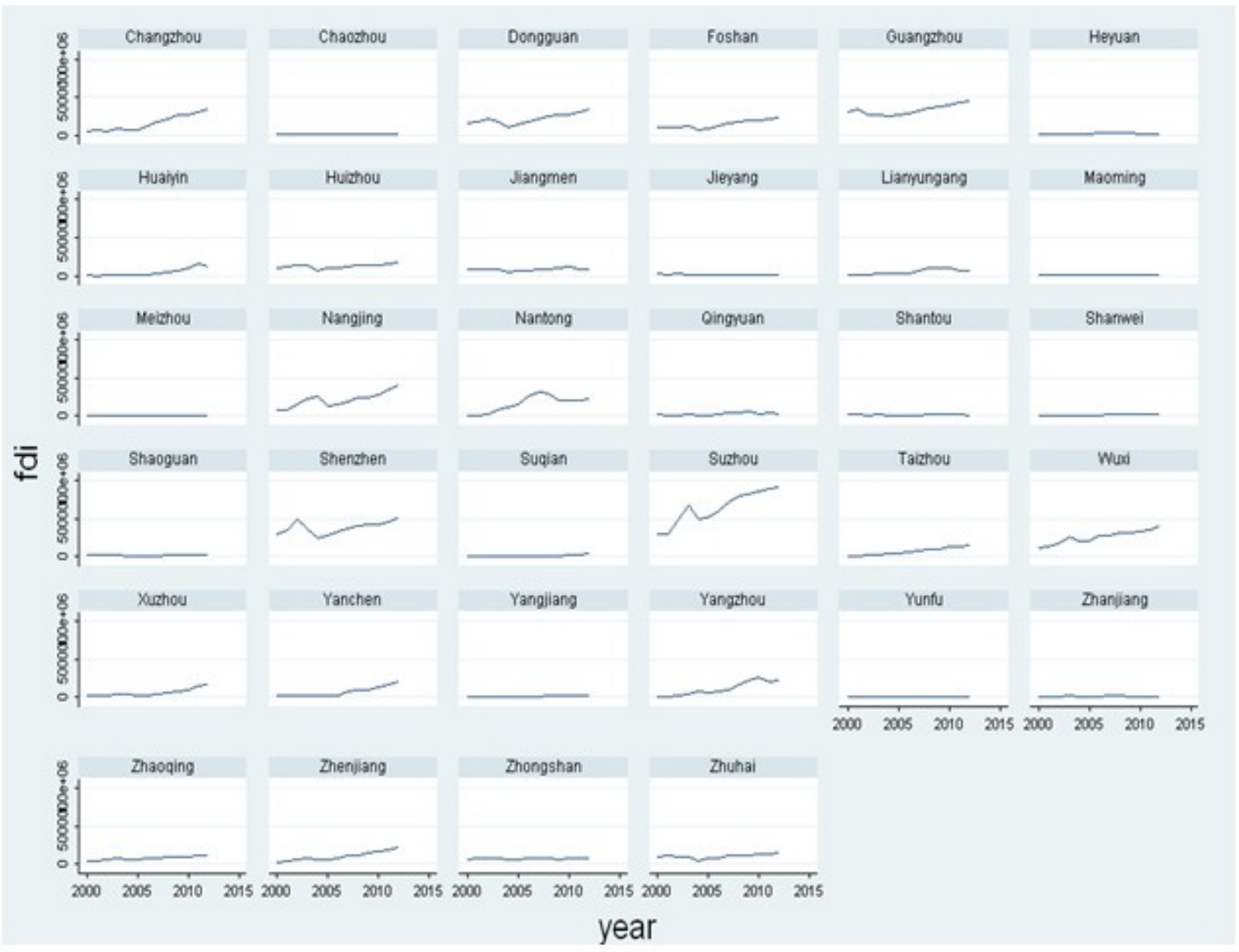

Figure 2. FDI trends change (2000-2012)

In the choice of indicators, the study selected the actual use of foreign capital as the indicator of FDI, the proportion of the total population of non-agricultural as urbanization rate (UR), the secondary and tertiary industries proportion of total output as industry structure (IS), GDP as the indicator economic growth. 


\subsection{Measurement Methods}

In this study, the paper uses panel data cointegration test to examine the long-term causality between FDI and urbanization. Engle and Granger (1987) pointed out that early cointegration between variables are the same order of each variable. So we should conduct panel unit root test before making panel data cointegration tests.

\subsubsection{Panel Data Unit Root Test}

Panel unit root test is a continuation and development of time series unit root test theory, which combines the features of time series and cross section; it can infer the existence of a unit root directly and accurately. In non-stationary panel data gradual process, Levin and Lin (1993) found that these limit distribution of estimator is Gaussian distribution, these results have also been used in heteroscedasticity panel data, and established early versions for unit panel root test. Later, Levin, Lin and Chu (2002) proposed LLC method of panel unit root test after improving it. Levin et al. (2002) noted that the method allows different intercept and time trend, variance and higher order serial correlation. Breituing (2000) proposed Breituing method of panel unit root test. Maddala and Wu (1999) proposed the ADF-Fisher and PP-Fisher panel unit root test methods.

\subsubsection{Panel Data Cointegration Analysis and Long-Term Causality Test}

Cointegration test is common method which tests long-run equilibrium relationship among variables. In order to test the long-term causality among variables, this paper uses the twostep test method which Engle and Granger (1987) proposed.

\subsubsection{Panel Data Error Correction Model and Short-Term Causality Test}

Cointegration relationship only reflects the long-term equilibrium relationship among variables, to compensate for the lack of long-term static model; we can reflect correction mechanism of short-term deviation from the long-run equilibrium through short-term dynamic models. Under the conditions of the long-term causality establishment, there is a need for short-term causality test and robustness analysis. Meanwhile, short-term causality test can further enhance understanding the short- run relationship between FDI and urbanization.

The unit root test must conduct because of the short data in this paper, to verify the existence of the long-term impact on urbanization rate of FDI. In this paper, the author use LLC method 
to test, if it through the test, he does not carry through cointegration and causality test, they do not have a unit root, the short- panel model stable.

\section{Results Analysis}

\subsection{Panel Data Unit Root Tests}

We conduct LLC unit root tests on four variables of LnFDI, LnUR, LnUS and LnGDP. The results shows unit root of LnFDI, LnUR, LnIS does not exist, but the unit root of LnGDP exists, the unit root does not exist after the first order difference, and the model becomes stable (Table 2 and Table 3).

\begin{tabular}{|c|c|c|c|c|c|c|}
\hline \multicolumn{3}{|c|}{ Variable } & LnFDI & LnUR & LnIS & $\begin{array}{l}\text { LnGDP/dL } \\
\text { nGDP }\end{array}$ \\
\hline \multirow{3}{*}{$\begin{array}{l}\text { The level } \\
\text { value }\end{array}$} & \multirow{3}{*}{ LLC } & Unadjusted value & -6.3767 & -4.0893 & -6.8900 & 1.7921 \\
\hline & & Adjusted value* & -5.2247 & -2.2691 & -4.6248 & 2.7878 \\
\hline & & P-value & 0.0000 & 0.0000 & 0.0000 & 0.351 \\
\hline \multirow{3}{*}{$\begin{array}{l}\text { First order } \\
\text { difference }\end{array}$} & \multirow{3}{*}{ LLC } & Unadjusted value & & & & -9.2493 \\
\hline & & Adjusted value* & & & & -4.0310 \\
\hline & & P-value & 0.0000 & 0.0000 & 0.0000 & 0.000 \\
\hline
\end{tabular}

Table 2. Results of panel unit root rest of Jiangsu province

\subsection{Hausman Test Panel Model}

When dealing with panel data, whether using a fixed effects model or random effects model, Hausman test should be conducted to determine. Table 4 and Table 5 are the Hausman test results.

\begin{tabular}{|c|c|c|c|c|c|c|}
\hline \multicolumn{3}{|c|}{ Variable } & LNFDI & LNUR & LNIS & LNGDP/dLNGDP \\
\hline \multirow{3}{*}{$\begin{array}{l}\text { The level } \\
\text { value }\end{array}$} & \multirow{3}{*}{ LLC } & Unadjusted $t$ & -6.9303 & -6.7409 & -9.6970 & -2.3742 \\
\hline & & Adjusted $\mathrm{t} *$ & -2.9571 & -4.2414 & -7.3397 & -1.6774 \\
\hline & & P-value & 0.0000 & 0.0000 & 0.0000 & 0.0467 \\
\hline \multirow{3}{*}{$\begin{array}{l}\text { First order } \\
\text { difference }\end{array}$} & \multirow{3}{*}{ LLC } & Unadjusted $t$ & & & & -12.8709 \\
\hline & & Adjusted $\mathrm{t} *$ & & & & -6.8184 \\
\hline & & P-value & 0.0000 & 0.0000 & 0.0000 & 0.0000 \\
\hline
\end{tabular}

Table 3. Results of panel unit root test of Guangdong province

\begin{tabular}{|l|r|r|r|r|}
\cline { 2 - 5 } \multicolumn{1}{c|}{} & \multicolumn{1}{c|}{ fe } & \multicolumn{1}{c|}{ re } & Difference & \multicolumn{1}{c|}{ S.E. } \\
\hline Inur & 2.000577 & 1.913784 & .0867933 & .047681 \\
\hline Ilngdp & -.0125769 & -.0126646 & .0000877 & .0002988 \\
\hline cons & 6.533676 & 7.068405 & -.5347294 & .3019673 \\
\hline Prob>chi2 = 0.2222 & -25.74645 & -27.81793 & 2.071479 & 1.274221 \\
\hline (V_b-V_B is not positive definite) & \multicolumn{3}{|c}{} \\
\end{tabular}

Table 4. Hausman test of panel model of Jiangsu province 


\begin{tabular}{|l|r|r|r|r|}
\cline { 2 - 5 } \multicolumn{1}{c|}{} & \multicolumn{1}{c|}{ fe } & \multicolumn{1}{c|}{ re } & Difference & S.E. \\
\hline dlngdp & -1.138085 & -1.08783 & -.0502551 & .0275496 \\
\hline Inis & .2097732 & .6297582 & -.4199851 & .1199104 \\
\hline cons & 2.878799 & 2.835852 & .0429469 & .0646334 \\
\hline Prob>chi2 = 0.0002 & -3.050035 & -4.547633 & 1.497598 & .414549 \\
(V_b-V_B is not positive definite)
\end{tabular}

Table 5. Hausman test of panel model of Guangdong province

Through Hausman test of Jiangsu province panel data, the p value is 0.2222 , accepting the null hypothesis, it is suitable for using a random effects model. For Guangdong province panel data, the value is 0.0002 , rejecting the null hypothesis "HO: ui and xit, zi is not relevant", it is suitable for using a fixed effects model, not random effects model.

\subsection{Random Effects Model And Fixed Effects Model}

$$
\text { LnFDIit }=\delta+\varphi \text { it }+\varphi \text { itLnISit }+ \text { itDLnGDPit }+\varphi \text { itLnURit }+\varepsilon
$$

The following results calculated by Stata software (Table 6 and Table 7):

\begin{tabular}{|c|c|c|c|c|c|}
\hline Infdi & Coef. & Std. Err. & $\mathbf{z}$ & $P>|z|$ & [95\% Conf. Interval] \\
\hline Inur & 1.913784 & .3192492 & 5.99 & 0.000 & $1.288067 \quad 2.5395$ \\
\hline Inis & 7.068405 & 1.166641 & 6.06 & 0.000 & 4.781839 .35498 \\
\hline dlngdp & -.0126646 & .0039698 & -3.19 & 0.001 & -.0204452 \\
\hline cons & -27.81793 & 4.360225 & -6.38 & 0.000 & $-36.36381-19.27204$ \\
\hline sigma_u & & & & & 44929744 \\
\hline sigma_e & & & & & .41812014 \\
\hline rho & & & & 53589 & tion of variance due to $u$ i) \\
\hline
\end{tabular}

Table 6. The result of Random effect model of panel data

Random effects model of Jiangsu province is:

$$
\text { LnFDIit }=-27.8179+1.9138 \text { LnURit }+7.0684 \text { LnISit-0.01266dLnGDPit }+0.8674
$$

Model shows, FDI was closely correlated with urbanization rate, the highly correlated with industrial structure, while it negatively correlated with the growth of GDP, and the degree of correlation is not high. The results show the industrial structure and the urbanization rate is the main cause FDI growth of Jiangsu province.

Fixed effects model of Guangdong province is:

$$
\text { LnGDFDIit=-3.0500-1.1381dLnGDPit +0.2098LnURit+2.8788LnISit+1.4117 }
$$

Guangdong panel model shows FDI is most relevant to industry structure, and has positive effect on urbanization rate, but negatively related to the GDP growth. There is the negative relationship between GDP growth and FDI, The stronger the economic power of Guangdong province, the less dependence on FDI. 


\begin{tabular}{|c|c|c|c|c|c|}
\hline Infdi & Coef. & Std. Err. & $z$ & $P>|z|$ & [95\% Conf. Interval] \\
\hline dlngdp & -1.138085 & .4370753 & -2.60 & 0.010 & $-1.999308-.2768619$ \\
\hline Inur & .2097732 & .2879985 & 0.73 & 0.000 & -.3577057 .7772521 \\
\hline Inis & 2.878799 & .418612 & 6.88 & 0.000 & 2.0539563 .703642 \\
\hline cons & -3.050035 & 1.56469 & -1.95 & 0.052 & -6.133137 .0330673 \\
\hline sigma_u & & & & & 1.0811316 \\
\hline sigma_e & & & & & .33357087 \\
\hline rho & & & & .91307 & ction of variance due to $u_{-} i$ ) \\
\hline
\end{tabular}

Table 7. The result of Fixed effect model of panel data of Guangdong province

\section{Conclusions}

This paper takes Jiangsu province and Guangdong province in costal areas as an example, analyzes the panel data (2000-2012) from 21 cities of Guangdong province and 13 cities of Jiangsu province, uses panel data unit root test and the Hausman test at the same time, it finds that the panel data of Jiangsu province is suitable for random effects model, and fixed effect panel data model is suitable for data of Guangdong province. Conclusion shows that the coastal areas is most areas to attract foreign direct investment, foreign direct investment (FDI) is strongly associated with secondary and tertiary industrial structure, and related to the urbanization level. FDI is closely related to the urbanization level in Jiangsu province, FDI promotes urbanization level, at the same time, higher urbanization level attracts more and more foreign capital, but urbanization level pulls small foreign investment. FDI is negatively related to the economic growth and greater inhibitory effect on FDI in Guangdong' GDP. The reasons follow:

- Firstly, it has been actively explored in implementing innovation-driven strategy and promoting industrial restructuring and upgrading and has made new achievements in promoting scientific and technological support vigorously, increasing efforts to introduce talents, enhancing construction of innovation carrier, exploring the new model of technology combined finance, encouraging multinational corporate localization in research and development in Jiangsu province in recent years. They established a longterm stable cooperative relationship between Jiangsu province and more than 70 countries and regions in science and technology, in the past five years they got 3000 international scientific and technological cooperation projects, established talent recruitment partnerships with 148 expert organizations in 26 developed countries, established 18 international cooperation base, and supports 26 local enterprises to establish overseas R \& D institutions. Foreign investment poured into the secondary and tertiary industries and has greatly affected the industrial structure.

Guangdong province regarded FDI as the main driving force since reform and opening up; it takes advantage of the adjacent to Hong Kong and Macao to develop the exportoriented economy, from the beginning of simple manufacturing to high-end manufacturing and production services and promotes industrial structure optimization. 
In recent years, Guangdong province can't keep pace with Jiangsu province in attracting FDI.

- Secondly, urbanization is the driving force of economic development and the main reason for attracting foreign investment. It needs a lot of money in the process of urbanization in Jiangsu province, FDI is an important source, so the city is also a major factor of FDI effect. Guangdong province has geographical advantages in the tertiary industry and infrastructure, etc, but regional development is imbalance, regional urbanization development requires a lot of investment in the north and the west of Guangdong province, and FDI can promote the rapid urbanization in the region.

- Thirdly, economic growth requires factors like technology, capital and labor force, but the economic restructuring is implemented in Jiangsu Province, the laws of economic growth showed economic growth decreased dependence on foreign capital, so the economic growth moves to innovation and industry restructuring to improve technology support, the impact of economic growth was smaller on FDI, or even negative. Endogenous economic growth is more powerful in Guangdong province, according to data, with the rise of GDP, FDI plays less role in economic growth, with the increase of labor cost and the industrial transformation, low added value of foreign capital gradually out of Guangdong, which showed a negative relationship between FDI and GDP.

Some advice follows:

- First, it should encourage multinational company localization and increase the introduction and training of innovative talents in the course of industrial structure adjustment and industrial transformation in Guangdong province and Jiangsu province. to further gather the excellent talents, Jiangsu province issued "high-level innovative entrepreneurial talent introduction plan", "two thousands of talents" project of scientific and technological innovation and entrepreneurship, "science and technology entrepreneurs plan", "enterprise youth Dr Plan". These talent plans are the fundamental driving force of promoting industrial structure transformation. Foreign capital utilization is in transition period in Jiangsu and Guangdong province, foreign capital is from laborintensive to capital and technology-intensive, human capital is the key to transformation' success, because the development of the capital and technologyintensive industries has always been to rely on high-tech and high-quality human resources. The development of service industry needs more and more high-level, highskill talents. Because many colleges and universities are in Jiangsu province and has good culture, so they should strengthen the cultivation of high-level personnel, cooperation of university-industry and improve the suitable high-quality talents for the economic and social development. In terms of human resources Guangdong province is inferior Jiangsu province, so they should introduce foreign talent through preferential 
policies, and strengthen the cultivation of the local talent. Two provinces can strengthen vocational training according to the requirements of the foreign capital enterprise, set up professional qualification standards system, the introduction of international modern management experience and the way of capital operation, and improve the intellectual resources to the development of service industry.

- Second, urbanization process allows foreign capital participation in urban infrastructure construction, real estate and so on. The central working conference of urbanization stressed that we should be people-oriented, promote the human-centered urbanization, and improve the quality of the urban population and the residents' quality of life. Establish a sustainable funding guarantee mechanism. Promote the reform of policybased financial institutions. Encourage social capital to participate in urban utilities investment operations. To attract more foreign capital to participate in urban public infrastructure, improve the foreign investment in the new urbanization. From the perspective of attracting foreign investment we should continue to promote the FDI inflows, optimize the industrial structure of two provinces, to speed up the urbanization process. From the perspective of the urban development we should break through the institutional obstacles such as the household registration management, land circulation, and social security. Through the optimization and improvement of urban infrastructure and service function, we enhance the capacity of the city of FDI inflows, attract nonagricultural production factors to urban agglomeration, and improve FDI inflows consistently, stably and healthily.

- Third, knowledge innovation and technological innovation will play important role in sustainable economic growth. Because of profit-driven capital, FDI may play fewer roles in technological innovation and knowledge innovation. The traditional mode of economic growth of Jiangsu province rely on investment, it should transform to new mode which rely on the innovation pattern of sustainable development. We should encourage scientific and technological innovation, develop the tertiary industry, support the development of high-tech industries, and actively support new urbanization, so as to achieve the new urbanization process. Economic growth has the negative effect on FDI inflows by data analysis, but it is a surface phenomenon, along with the economic growth, Guangdong and Jiangsu province pay more attention to the quality of foreign investment, from the traditional simple manufacturing to high technology and productive service industry, thus improve the enterprises' competitiveness of the two provinces throughout the country and the world. 


\section{References}

Blomstrom, M. (1986). Foreign Investment and Productive Efficiency: The Case of Mexico. The Journal of Industrial Economic, 35, 97-110. http://dx.doi.org/10.2307/2098609

Borensztein, E., De Gregorio, J., \& Lee, J.-W. (1998). How does Foreign Direct Investment Affect Economic Growth?. Journal of International Economics, 45, 115-135.

Breituing, J. (2000). A parameter approach to the estimation of cointegration vectors in panel data. Working paper, Humboldt University. http://dx.doi.org/10.1016/S0022-1996(97)00033-0

Chang-Biao, Z. (2010). Empirical Evidence on the Regional Spillover Effects of FDI in China. Economic Research, 1, 80-89.

Chao-Lin, G. (2003). Urbanization Studies: An International Approach. City Planning Review, $6,19-24$.

Chase-Dunn, C. (1975). The Effects of International Economic Dependence on development and Inequality: A Cross-National Study. American Sociological Review, 40, 720-738. http://dx.doi.org/10.2307/2094176

Clark, D. (1998). Interdependent Urbanization in Urban World: A Historical Overview. The Geographical Journal, 164(1), 85-95. http://dx.doi.org/10.2307/3060547

Deng, N. (2000). Study on China's Urbanization Mechanism in the 21st Century. Urban Planning Forum, 3, 41-46.

Dian-Chun, J., \& Yu, Z. (2008). Institutional Constraints on FDI Productivity Spillovers: The Case of China. Economic Research, 7, 26-38.

Engle, R., \& Granger, C. (1987). Co-integration and Error Correction: Representation, Estimation, and Testing. Econometrica, 55, 251-276. http://dx.doi.org/10.2307/1913236

Fan, F. (2011). Analysis on Relationship of FDI and City in Jiang Zhe Hu areas. Journal of Economic Study, 30, 159-162.

Fang, C., \& De-Wen, W. (2004). Foreign Direct Investment and Its Employment Effects in China on Analyses of Human Capital. Collected Essays on Finance and Economics, 1, 1-14.

Fei, X., \& Jian-Hua, Z. (2009). Impact of Foreign Technology Transfer on Indigenous R\&D in China. Economic Research, 6, 94-104.

Feng-Xuan, X., \& Chun, Y. (1995). Urbanization under foreign influence-The Case of the Pearl River Delta. Urban Planning, 19(6), 21-27. 
Feng-Xuan, X., \& Chun, Y. (1997). Exo-urbanization: The Case of Zhujiang River Delta. Acta Geographica Sinca, 3, 193-205.

Firebaugh, G. (1992). Growth Effects of Foreign and Domestic Investment. The American Journal of Sociology, 98, 105-130. http://dx.doi.org/10.1086/229970

Firman, T., Kombaitan, B., \& Pradono, P. (2007). Dynamics of Indonesia's Urbanization, 19802006. Urban Policy and Research, 25(4), 433-454. http://dx.doi.org/10.1080/08111140701540752

Friedmann, J. (1986). The world City Hypothesis. Development and Change,17, 69-73. http://dx.doi.org/10.1111/j.1467-7660.1986.tb00231.x

Fujita, M., \& Hu, D. (2001). Regional disparity in China 1985-1994: The effects of Globalization and economic liberalization. The Annals of Regional Science, 35, 3-37. http://dx.doi.org/10.1007/s001680000020

George, C.S. Lin (2007). Reproducing Spaces of Chinese Urbanization: New City-based and Land centered Urban Transformation. Urban Studies, 44(9), 1827-1855. http://dx.doi.org/10.1080/00420980701426673

Guang-zhong, C., Yi-xing, Z., \& Lin, Y. (1994). Multivariate Analysis on China's Urban Economic Growth. Economic Geography, 2, 31-37.

Hong, Z. (2001). Development Zone Promoting Urbanization Mode-Case Study of Yangtze Delta. Urban Planning Forum, 6, 65-69.

Ji-Yong, C., \& Yang-Yi, S. (2008). An Empirical Study on FDI International Knowledge Spillovers and Regional Economic Development in China Economic Research. Economic Research, 12, 39-49.

Ji-zeng, W. (2013). An empirical analysis of the interactive relationship between FDI, urbanization and economic growth. Finance and Economics, 1,3 0-33.

Juan, H., Feng, S., \& Peng-Fei, L. (2011). Empirical Analysis on Impact of FDI on The Level of Urbanization-Basing on the Panel Date of China's 21 Cities from 2003 to 2007. Economic Problems, 4, 44-47.

Kai-Ming, C., \& Cun-Zhang, D. (2010). Analysis of regional disparities on China's FDI location distribution factors. Economic Geography, 1, 99-103.

Kasarda, J.D., \& Crenshaw, E.M. (1991). Third World Urbanization: Dimensions, Theories and Determinants. Annual Review of Sociology,17, 467-501.

http://dx.doi.org/10.1146/annurev.so.17.080191.002343 
Kentor, J. (1981). Structural Determinants of Peripheral Urbanization: The Effects of International Dependence. American Sociological Review, 46, 201-211.

http://dx.doi.org/10.2307/2094979

Levin, A., Lin, C., \& Chu, C. (2002). Unit root test in panel data asymptotic and finite sample properties. Journal Econometrics, 10, 1-24. http://dx.doi.org/10.1016/S0304-4076(01)00098-7

Levin, A., \& Lin, C.F. (1993). Unit Root Test in Panel Data: New Results, University of California at San Diego. Discussion Paper, 1, 93-56.

Lin Ji, L., \& Lai-Ke, Y. (2013). Foreign direct investment and the level of city growth. Modern management science, 4, 64-66.

Liu, X. \& Parker, D. (2001). Foreign direct investment and productivity spillovers in the Chinese manufacturing sector. Economic Systems, 25(4), 305-321. http://dx.doi.org/10.1016/S09393625(01)00029-2

Lloyd, P.J. (1996). Role of Foreign Investment in the Success of Asian Industrialization. Journal of Asian Economic, 7, 407-433. http://dx.doi.org/10.1016/S1049-0078(96)90019-6

Maddala, G.S., \& Wu, S. (1999). A Comparative Study of Unit Root Tests with Panel Data and a New Simple Test. Oxford Bulletin of Economics and Statistics, special issue, 1, 631-652. http://dx.doi.org/10.1111/1468-0084.61.s1.13

Portes, A., \& Johns, M. (1986). Class Structural and Spatial Urbanization: An Assessment of Recent Urban Trends in Latin America. Tijdsehriftvoor Economische en Sociale geografie, 77, 78-88.

Romer, P.M. (1990). Endogenous Technological Change. Journal of Political Economy, 98, 71-102. http://dx.doi.org/10.1086/261725

Romer, P.M. (1994). Origins of Endogenous Growth. The Journal of Economic Perspectives, 8, 3-22. http://dx.doi.org/10.1257/jep.8.1.3

Rong-lin, W. (2010). FDI and Urbanization: A case study of cities in Jiangsu Province. Journal of Xinyang Normal University, 10, 254-256.

Timberlake, M., \& Kentor, J. (1983). Economic Dependence, Overurbanization, and Economic Growth: A Study of Less Developed Countries. Sociological Quarterly, 24(3), 489-507. http://dx.doi.org/10.1111/j.1533-8525.1983.tb00715.x

Xi, L. (2008). An Empirical Analysis of FDI to promote the urbanization process in China. Journal of Capital University of Economics and Business, 3, 16-22. 
Xiu-Yu, Z., \& Hong-Quan, C. (2009). An empirical study of Guangdong Province and the relationship between FDI and City. Science and Technology Management Research, 11, 124127.

Yi-Shao, S., \& Meng-Jing, G. (2003). Development of Urbanization Drived by Foreign Capital in the Yangtze River Delta. Modern Urban Research, 4, 1-7.

Yue-Min, N. (1998). New Urbanization-Investigation on the dynamic mechanism and features of China's urbanization since 1990s. Acta Geographica Sinca, 53(5), 470-477.

Journal of Industrial Engineering and Management, 2015 (www.jiem.org)

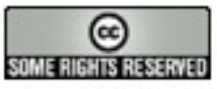

Article's contents are provided on a Attribution-Non Commercial 3.0 Creative commons license. Readers are allowed to copy, distribute and communicate article's contents, provided the author's and Journal of Industrial Engineering and Management's names are included. It must not be used for commercial purposes. To see the complete license contents, please visit http://creativecommons.org/licenses/by-nc/3.0/. 